\title{
The Cognition and Implementation of Junior High School Teachers in Changhua County on Differentiated Instruction for 12-Year Basic Education
}

\author{
Ta-Chun Chang, Chin-Chang Wu, Ming-Shang Su, and Chin-Wen Liao
}

\begin{abstract}
This research is to study the cognition and implementation of Junior High School Teachers in Changhua County on Differentiated Instruction for 12-year Basic Education. Furthermore, the different background variables of the junior high school teachers about the cognition of differentiated instruction and the difference on implementation of differentiated instruction has been studied.

Questionnaire was applied in this research. The official teachers of public junior high schools in Changhua County were the study population. The stratified cluster sampling has been applied and 18 schools were selected to implement questionnaire survey. There were 600 questionnaires released and 557 valid questionnaires were returned. The valid retrieving rate is $92.83 \%$. After the data collection, the statistical application SPSS was used to implement the data analysis and induce the conclusion by frequency distribution, percentage, mean, standard deviation, T-test, one-way. ANOVA, Scheffé Test and Pearson's product-moment.
\end{abstract}

Index Terms-12-year basic education, junior high school teacher, cognition on differentiated instruction, implementation on differentiated instruction.

\section{BACKGROUND AND MOTIVATION}

\section{A. Research Background}

The society of Taiwan becomes open and diversified. The immigrants, extreme disparity between the rich and the poor, and the promotion of inclusive education make the students in the classes become more diversified [1]. Starting from the semester of 2014, the Ministry of Education promotes 12-year Basic Education [2]. This important educational revolution brings a lot of impact to educational world. The educational ecology of middle schools is also changed. The open admission extends the differentiation of the school internally. The ability and potential of the students become diversified. The teachers face the challenge on teaching students in accordance with their aptitude, learning assessment and talent development [3].

\section{B. Motivation}

In order to address the practical teaching difficulty of

Manuscript received April 20, 2015; revised July 23, 2015.

Ta-Chun Chang, Chin-Chang Wu, and Ming-Shang Su are with the Department of Industrial Education, National Changhua University (NCUE), Taiwan, R.O.C. (e-mail: jackncue@gmail.com,wsh1102@yahoo.com.tw, zacd1234@yahoo.com.tw).

Chin-Wen Liao is with the Department of Industrial Education and Technology, National Changhua University of Education (NCUE), Taiwan, R.O.C. (e-mail: tcwliao@cc.ncue.edu.tw). teachers in schools, scholars purpose the concept of differentiated instruction and teaching strategy. The Ministry of Education is also planning the students learning support system and implementing the improvement of differentiated instruction for teachers in elementary and junior high schools. The sustainable promotion of differentiated instruction relies on building up the professional level of the teachers and the establishment of the overall system. Therefore, we should pay much attention to the development of professional differentiated instruction for teachers in different domains and professional levels. Thus, one of the motivations of this research is to understand the cognition of junior high school teachers on differentiated instruction for 12-year Basic Education.

In recent years, the schools in western countries pay high attention to differentiated instruction. The differentiated instruction has been introduced to the lessons gradually. According to most of the researches, differentiated instruction can significantly increase the performance of students learning and teachers teaching [4]. To response to the diversity of students, are the teachers able to update their own teaching concepts with the change of system after the promotion of 12-year Basic Education, and further implement differentiated instruction effectively? Is the administration able supporting the differentiated instruction effectively? What problems and difficulties do the teachers face during the implementation? The second motivation of this research is to understand the existing circumstance teachers in junior high schools implementing differentiated instruction.

To respond to the implementation of 12-year Basic Education, the Ministry of Education (2012) has introduced "Teacher Specialty 519" scheme. All the teachers are required to complete 5 lessons (18 hours) about the teachers' specialty study within one year [2]. The objective of the study is to increase the professional skill of the teachers. It is expected to activate the teaching and assist the students learning effectively. Under such raging trend of reform, the third motivation of this research is to understand whether the front line teachers in Chunghwa County junior high schools can increase the cognition on differentiated instruction and implement effectively through the skill improvement scheme planned by Ministry of Education.

\section{OBJECTIVE}

According to the background and motivation, the objectives of this research include the following items:

1) Understand the cognition and implementation of junior 
high school teachers in Changhua County on differentiated instruction for 12-year Basic Education.

2) Analyze the different background variables of the junior high school teachers in Changhua County about the different cognition of differentiated instruction for 12-year Basic Education.

3) Analyze the different background variables of the junior high school teachers in Changhua County about the different implementation of differentiated instruction for 12-year Basic Education.

4) Study the relationship of cognition and implementation of junior high school teachers in Changhua County on differentiated instruction for 12-year Basic Education.

\section{RESEARCH DESIGN AND IMPLEMENTATION}

\section{A. Research Structure}

This research structure drafted the possible relationship between the variables. The basic structure of the research is established. The personal background of the teachers is the independent variable. The research structure is shown in Fig. 1 .

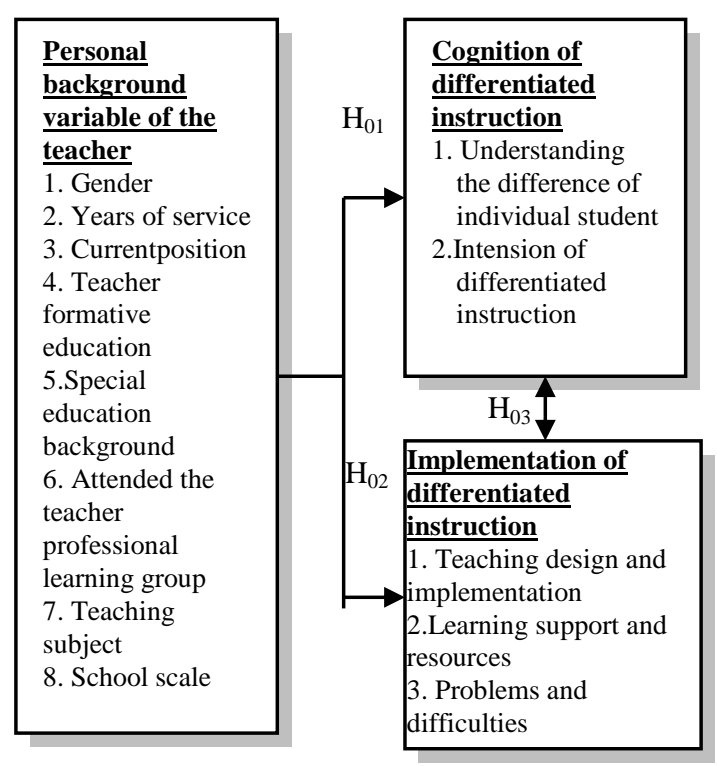

Fig. 1. Research structure.

\section{B. Object of Study}

The object of study is the official teachers of public junior high schools (including the junior high school of comprehensive Junior-Senior high schools) in 2013 semester in Changhua County. The corresponding distribution is summarized in Table I.

\section{1) Object of pre-test questionnaire}

After the validity examination of the questionnaire by experts, the pre-test questionnaire was implemented. According to the population of school scale, the stratified cluster sampling was applied to 7 schools. The pre-test questionnaire was implemented from 1-Mar-2014 to 20-Mar-2014. 160 questionnaires were delivered and 155 questionnaires were returned. After ignoring the invalid questionnaire, there were 154 valid questionnaires. The distribution of pre-test questionnaire sampling schools is listed in Table II.

TABLE I: LIST OF JUNIOR HIGH SCHOOLS IN 2013 SEMESTER IN CHANGHUA COUNTY

\begin{tabular}{lllll}
\hline School scale & $\begin{array}{l}\text { No. of } \\
\text { school }\end{array}$ & $\begin{array}{c}\text { Percentage of } \\
\text { schools }(\%)\end{array}$ & $\begin{array}{l}\text { No. of } \\
\text { teacher }\end{array}$ & $\begin{array}{l}\text { Percentage of } \\
\text { teacher }(\%)\end{array}$ \\
\hline $\begin{array}{l}12 \text { classes or } \\
\text { below }\end{array}$ & 5 & 12 & 112 & 3 \\
\hline $\begin{array}{l}13 \sim 24 \\
\text { classes }\end{array}$ & 8 & 20 & 382 & 11 \\
\hline $\begin{array}{l}25 \sim 48 \\
\text { classes }\end{array}$ & 16 & 39 & 1,279 & 37 \\
\hline $\begin{array}{l}49 \text { classes or } \\
\text { above }\end{array}$ & 12 & 29 & 1,680 & 49 \\
\hline Total & 41 & 100 & 3,453 & 100 \\
\hline \multicolumn{5}{c}{ Source: Arranged by this research }
\end{tabular}

Source: Arranged by this research

TABLE II: THE DisTRIBUTION LIST OF PRE-TEST QUESTIONNAIRE SAMPLING SCHOOLS

\begin{tabular}{lllll}
\hline $\begin{array}{l}\text { School } \\
\text { scale }\end{array}$ & $\begin{array}{l}\text { No. of } \\
\text { school }\end{array}$ & $\begin{array}{l}\text { Percentage } \\
\text { of teacher } \\
(\%)\end{array}$ & $\begin{array}{l}\text { No. of sampling } \\
\text { school }\end{array}$ & $\begin{array}{l}\text { No. of } \\
\text { pre-test } \\
\text { sampling }\end{array}$ \\
\hline $\begin{array}{l}\text { 12classes } \\
\text { or below }\end{array}$ & 5 & 3 & 1 & 10 \\
\hline $\begin{array}{l}13 \sim 24 \\
\text { classes }\end{array}$ & 8 & 11 & 1 & 20 \\
\hline $\begin{array}{l}25 \sim 48 \\
\text { classes }\end{array}$ & 16 & 37 & 2 & 50 \\
\hline $\begin{array}{l}49 \text { classes } \\
\text { or above }\end{array}$ & 12 & 49 & 3 & 80 \\
\hline Total & 41 & 100 & 7 & 160 \\
\hline \multicolumn{4}{c}{ Source: Arranged by this research }
\end{tabular}

\section{2) Object of official questionnaire}

In order to make the sample more representative, the official sampling were classified as 12 classes or below, 13 24 classes, 25 48 classes and 49 classes or above according to the school scale. The stratified cluster sampling was applied. There were 600 questionnaires delivered and 561 questionnaires were returned. After the invalid questionnaires were ignored, there were 557 valid questionnaires. The distribution of sampling schools of official questionnaires is shown in Table III.

TABLE III: LIST OF SAMPLING SCHOOLS OF OFFICIAL QUESTIONNAIRES

\begin{tabular}{llclll}
\hline $\begin{array}{l}\text { School } \\
\text { scale }\end{array}$ & $\begin{array}{l}\text { No. of } \\
\text { school }\end{array}$ & $\begin{array}{l}\text { No. of } \\
\text { teacher }\end{array}$ & $\begin{array}{l}\text { Percentage } \\
\text { of teacher }\end{array}$ & $\begin{array}{l}\text { No. of } \\
\text { sampling } \\
\text { school }\end{array}$ & $\begin{array}{l}\text { No. of } \\
\text { sampling }\end{array}$ \\
\hline $\begin{array}{l}\text { 12classes } \\
\text { or below }\end{array}$ & 5 & 112 & 3 & 2 & 20 \\
\hline $\begin{array}{l}13 \sim 24 \\
\text { classes }\end{array}$ & 8 & 382 & 11 & 4 & 60 \\
\hline $\begin{array}{l}25 \sim 48 \\
\text { classes }\end{array}$ & 16 & 1,279 & 37 & 6 & 240 \\
\hline $\begin{array}{l}49 \text { classes } \\
\text { or above }\end{array}$ & 12 & 1,680 & 49 & 6 & 280 \\
\hline Total & 41 & 3,453 & 100 & 18 & 600 \\
\hline \multicolumn{7}{l}{ Source: Arranged by this research }
\end{tabular}

\section{Research Tools}

Questionnaire has been applied in this research. In order to achieve the objective of this research, the relevant literatures were collected first. According to the research structure, the relevant information is arranged. Finally, "The cognition and 
implementation of junior high school teachers on Differentiated Instruction for 12-year Basic Education Questionnaire" was written as the research tool of this research. The composing procedure and the contents are described below:

\section{1) Designing the structure and first draft}

This research can analyze the cognition and implementation of junior high school teachers on differentiated instruction for 12-year Basic Education objectively. The theory of this research is based on studying of literatures and the first draft of questionnaires was developed.

\section{2) Establishing the validity of expert contents}

After the first draft of this questionnaire was written, the adviser read and revised. Then the scholars and representatives of junior high school teachers were invited to provide recommendation about the suitability of the topic and the wording of the questionnaire. This is to establish the validity of expert contents of this research tool and will be the important reference for revising the official questionnaire.

\section{3) Implementation of pre-test and the result analysis}

After the first draft of questionnaire is completed, in order to understand the adequacy and usability of the questionnaire, the pre-test was started at once. The pre-test questionnaires were delivered since March or 2014 continually. In order to achieve better construct validity and reliability of this research tool, after the pre-test questionnaires were returned, the statistical application was applied to analyze the item analysis, factor analysis and Cronbach's $\alpha$ Test. The validity and reliability of this questionnaire were tested and they became the reference of choosing the questions of the official questionnaire [5].

\section{4) Official questionnaire}

The pre-test questionnaire of this research was revised according to the suggestions of the experts and scholars. Then item analysis, factor analysis, and reliability were analyzed. After deleting the improper questions, the official questionnaire was edited.

\section{Survey Implementation}

This research was implemented starting from Sep 2014 to draft the topic, study the literatures, and classify the object of study. On 25-Jan-2014, the dissertation proposal defense was implemented. On Feb 2014, according to the suggestion of inspection committee, the review and adjustment were implemented, and the pre-test questionnaire was adjusted and printed. On early of March 2014, the pre-test questionnaires were delivered to the selected junior high schools. Besides, on late of March 2014, the pre-test questionnaires were returned, arranged and compiled statistics. On May 2014, after the official questionnaire was finalized, the questionnaires of cognition and implementation of junior high school teachers on differentiated instruction for 12-year Basic Education was delivered. Then the questionnaires were returned and arranged.

\section{E. Data Processing}

The questionnaire was applied for this research. The questionnaires were returned on Jun 2013. After the questionnaires were returned, each questionnaire was checked manually to ignore the invalid questionnaires, including the incomplete answers, regular response and unreasonable answers. Then each questionnaire was assigned a code and filed. Then, the statistical application was applied to compile statistics.

\section{DATA ANALYSIS AND DISCUSSION}

\section{A. Background Variables Analysis of Teachers}

1) Gender: most of them are female teachers, which occupies around $65 \%$.

2) Years of service: most of the samples are teachers serving for 6-19 years and 11-15 years, for which they occupy around $50 \%$ of valid samples.

3) Current position: most of the samples are teachers who also serve as tutor of the class, for which they occupy around $55 \%$ of valid sample.

4) Teacher formative education: most of the samples were graduated from normal university, for which they occupy around $55 \%$ of valid sample.

5) Special education background: the ratio of teachers without and with special education background is 6:4.

6) Attended the teacher professional learning group: most of the samples have never attend the teacher professional learning group, for which they occupy around $70 \%$.

7) Teaching subject: the teachers teaching Chinese, English, Mathematics, Science and Technology, society and other subjects occupy $25.3 \%, 14.2 \%, 14.7 \%, 17.4 \%, 14.5 \%$ and $13.8 \%$ respectively.

8) School scale: most of the samples come from school scale with 49 classes or above which occupy $47 \%$.

\section{B. Analysis on the Cognition of Junior High School Teachers on Differentiated Instruction for 12-Year Basic Education}

The average scores of "understanding the individual difference of student", "intension of differentiated instruction" and "advantages of differentiated instruction" in the differentiated instruction cognition scale are between 4.11 and 4.45. This means that the junior high school teachers trend towards "agree" on different levels of cognition of differentiated instruction. The overall average scores are 4.25, which show that the junior high school teachers trend towards "agree" on overall cognition of differentiated instruction. The result is shown in Table IV.

\section{Analysis on the Implementation of Junior High School Teachers on Differentiated Instruction for 12-Year Basic Education}

The average scores of "teaching design and implementation" and "learning support and resource" in the differentiated instruction scale are 3.47 and 3.20 respectively. This shows that the coincidence of junior high school teachers on differentiated instruction is "fair". The "problems and difficulties" is reverse scoring. The average score is 2.38 , which shows that the junior high school teachers trend to "coincident" to implementation of differentiated instruction. The overall average score of implementation of differentiated instruction is 3.12. It can induce that the junior high school 
teachers trend to "fair" to implementation of differentiated instruction. The result is shown in Table V.

TABLE IV: DIFFERENT LEVEL OF DESCRIPTION AND ANALYSIS ON THE COGNITION OF JUNIOR HIGH SCHOOL TEACHERS ON DIFFERENTIATED INSTRUCTION FOR 12-YEAR BASIC EDUCATION

\begin{tabular}{llllll}
\hline $\begin{array}{l}\text { Name } \\
\text { of scale }\end{array}$ & Factor & Average score & $\begin{array}{l}\text { Standard } \\
\text { Deviation }\end{array}$ & \multicolumn{2}{c}{ Score in order Cognitive level } \\
\hline \multirow{3}{*}{$\begin{array}{l}\text { Cognition on differentiated } \\
\text { instruction }\end{array}$} & Understanding the individual difference of student 4.45 & .43 & 1 & Agree \\
\cline { 2 - 7 } & Intension of differentiated instruction & 4.26 & .45 & 2 & Agree \\
\cline { 2 - 7 } & Advantages of differentiated instruction & 4.11 & .59 & 3 & Agree \\
\cline { 2 - 7 } & Overall & 4.26 & .52 & & Agree \\
\hline
\end{tabular}

$N=557$

TABLE V: DESCRIPTION AND ANALYSIS OF DIFFERENT FACTORS OF JUNIOR HIGH SCHOOL TEACHERS ON DIFFERENTIATED INSTRUCTION FOR 12-YEAR BASIC EDUCATION

\begin{tabular}{|c|c|c|c|c|c|}
\hline Name of scale & Factor & Average score & Standard Deviation & Score in order & Cognitive level \\
\hline \multirow{4}{*}{$\begin{array}{l}\text { Implementation of } \\
\text { Differentiated }\end{array}$} & $\begin{array}{l}\text { teaching design and } \\
\text { implementation }\end{array}$ & 3.47 & .61 & 1 & Fair \\
\hline & learning support and resource & 3.20 & .71 & 2 & Fair \\
\hline & Problems and difficulties & 2.38 & .61 & 3 & coincident \\
\hline & Overall & 3.12 & .48 & & Fair \\
\hline
\end{tabular}

TABLE VI: SUMMARY OF HYPOTHESIS AND THE PROVEN RESULT

Hypothesis

$\mathrm{H}_{01-1}$ No significant difference for cognition of junior high school teacher with different gender on differentiated instruction for 12-year Basic Education.

$\mathrm{H}_{01-2}$ No significant difference for cognition of junior high school teacher with different years of service on differentiated instruction for 12-year Basic Education.

$\mathrm{H}_{01-3}$ No significant difference for cognition of junior high school teacher with different current position on differentiated instruction for 12-year Basic Education.

$\mathrm{H}_{01-4}$ No significant difference for cognition of junior high school teacher with different teacher formative education on differentiated instruction for 12-year Basic Education

$\mathrm{H}_{01-5}$ No significant difference for cognition of junior high school teacher with different special education background on differentiated instruction for 12-year Basic Education

$\mathrm{H}_{01-6}$ No significant difference for cognition of junior high school teacher with different attended professional learning group on differentiated instruction for 12-year Basic Education

$\mathrm{H}_{01-7}$ No significant difference for cognition of junior high school teacher with different teaching subject on differentiated instruction for 12-year Basic Education.

$\mathrm{H}_{01-8}$ No significant difference for cognition of junior high school teacher with different school scale on differentiated instruction for 12-year Basic Education.

$\mathrm{H}_{02-1}$ No significant difference for implementation of junior high school teacher with different gender on differentiated instruction for 12-year Basic Education.

$\mathrm{H}_{02-2}$ No significant difference for implementation of junior high school teacher with different years of service on differentiated instruction for 12-year Basic Education

$\mathrm{H}_{02-3}$ No significant difference for implementation of junior high school teacher with different current position on differentiated instruction for 12-year Basic Education

$\mathrm{H}_{02-4}$ No significant difference for implementation of junior high school teacher with different teacher formative education on differentiated instruction for 12-year Basic Education.

$\mathrm{H}_{02-5}$ No significant difference for implementation of junior high school teacher with different special education background on differentiated instruction for 12-year Basic Education

$\mathrm{H}_{02-6}$ No significant difference for implementation of junior high school teacher with different attended professional learning group on differentiated instruction for 12-year Basic Education

$\mathrm{H}_{02-7}$ No significant difference for implementation of junior high school teacher with different teaching subject on differentiated instruction for 12-year Basic Education

$\mathrm{H}_{02-8}$ No significant difference for implementation of junior high school teacher with different school scale on differentiated instruction for 12-year Basic Education.

$\mathrm{H}_{03}$ No significant difference for cognition and implementation of junior high school teacher on differentiated instruction for 12-year Basic Education.

Note:'○'It reaches significant and unproven hypothesis is rejected

D. Cognition and Implementation of Junior High School

Teachers on Differentiated Instruction for 12-Year Basic

Education
The hypothesis and the proven results of this research are shown in Table VI.

Next, the different background variables and the proven result of hypothesis are summarized in Table VII. 


\begin{tabular}{|c|c|c|c|c|c|c|c|c|c|}
\hline & $\begin{array}{r}\text { Background } \\
\text { variable }\end{array}$ & Gender & $\begin{array}{l}\text { Years } \\
\text { of } \\
\text { service }\end{array}$ & $\begin{array}{l}\text { Current } \\
\text { position }\end{array}$ & $\begin{array}{l}\text { Teacher } \\
\text { formative } \\
\text { education }\end{array}$ & $\begin{array}{c}\text { Special } \\
\text { education } \\
\text { background }\end{array}$ & $\begin{array}{c}\text { attended } \\
\text { professional } \\
\text { learning group }\end{array}$ & $\begin{array}{l}\text { Teaching } \\
\text { subject }\end{array}$ & $\begin{array}{l}\text { School } \\
\text { scale }\end{array}$ \\
\hline \multicolumn{10}{|l|}{ Aspect } \\
\hline \multirow{4}{*}{$\begin{array}{l}\text { Cognition on differentiated } \\
\text { instruction }\end{array}$} & $\begin{array}{l}\text { understanding the individual } \\
\text { difference of student }\end{array}$ & & & & & & (a) & & \\
\hline & $\begin{array}{l}\text { intension of differentiated } \\
\text { instruction }\end{array}$ & & & () & & & (a) & & \\
\hline & $\begin{array}{l}\text { advantages of differentiated } \\
\text { instruction }\end{array}$ & & & (a) & & & (a) & & \\
\hline & $\begin{array}{l}\text { Cognition on differentiated } \\
\text { instruction }\end{array}$ & & & ()) & & & (a) & & \\
\hline \multirow{4}{*}{$\begin{array}{l}\text { Implementation on } \\
\text { differentiated instruction }\end{array}$} & $\begin{array}{l}\text { Teaching design and } \\
\text { implementation }\end{array}$ & (a) & & (a) & & (C) & (a) & (a) & \\
\hline & Learning support and resource & (a) & (a) & (a) & (a) & & (a) & (a) & \\
\hline & Problems and difficulties & & & & & & (a) & (a) & \\
\hline & $\begin{array}{l}\text { Implementation on differentiated } \\
\text { instruction }\end{array}$ & (2) & & (2) & (2) & & (a) & (2) & (a) \\
\hline
\end{tabular}

\section{CONCLUSION AND SUGGESTION}

\section{A. Conclusion}

After the comprehensive analysis and discussion, the results are described below according to the objectives of the research:

1) The junior high school teachers have middle or above level of cognition on differentiated instruction.

2) The junior high school teachers are coincident to middle level of implementation on differentiated instruction.

3) The junior high school teachers who serve administrative job concurrently or attended professional learning group have the highest level of cognition on differentiated instruction.

4) The junior high school teachers who teach in large-scale schools, have special education background, graduated from non-normal schools, attended professional learning group, and young male teachers teaching non-academic subject are coincident to the highest level of implementation on differentiated instruction.

5) The junior high school teachers with higher cognition on differentiated instruction, they are also coincident to higher level of implementation on differentiated instruction.

\section{B. Suggestion}

According to the data collected from questionnaire and the corresponding analysis, this research proposes the following suggestion to the education administration authority, school administration, and teachers:

\section{1) About the education administration authority}

1) Increase the competence of teachers on differentiated instruction.

2) Reduce the number of student in class and implement small class education.

\section{2) About the school administration}

1) Integrate the supports and resources. Assist the teachers implementing differentiated instruction actively.

2) Organize the teacher professional learning groups.
Promote the interchange and passing down of experience.

3) Integrate the learning information of the students. Assist the teachers to understand the individual difference and learning requirement.

\section{3) About the teachers}

1) Actively attend the teacher professional group and improve the teaching competence.

2) Pay attention to teamwork and establish the learning community.

\section{REFERENCES}

[1] R. I. A. Arends and A. Kilcher, "Instructional differentiation," Teaching for Student Learning: Becoming an Accomplished Teacher, New York, NY: Routledge, pp. 105-130, 2010.

[2] Ministry of Education. (2012). Establishment of Ministry of Education 12-Year Basic Education Learning Support System and Teachers Teaching Competence Improvement Implementation Principal Points. [Online]. http://edu.law.moe.gov.tw/LawContent.aspx?id=GL000963

[3] T.-M. Xu and X.-L. Zhen. (2013). Establishment of school learning support system. [Online]. Available: https://docs.google.com/file/d/0Bzg8vZDOUQ8rNlkycWlnVW5GW $\mathrm{mM} /$ edit?usp=sharing\&pli $=1$

[4] Y.-M. Jian and M.-L. Qiu, "The application of differentiated instruction for the teacher community to enhance reading competence," Journal of Educational Research, vol. 233, pp. 61-78, 2013.

[5] M.-L. Wu, SPSS Statistics Practical Learning: Questionnaire Analysis and Applied Statistics, New Taipei: Acore, 2011.

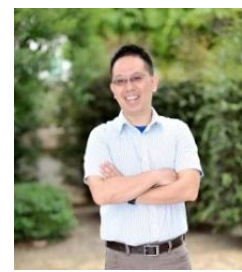

Ta-Chun Chang received his M.S. degree at the Department of Industrial Education from National Changhua University in 2001, and currently he is a doctoral student at the Department of Industrial Education from National Changhua University, Taiwan, R.O.C. Since August 2014, he has been a director of student affairs in Taichung Municipal Lishin Junior High School in Taiwan, R.O.C. Since August 2013, he has taught courses in mathematics study in the same school.

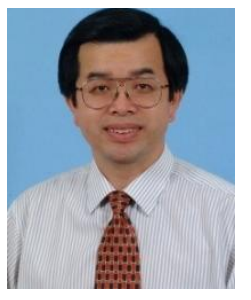

Chin-Chang Wu received his M.S. degree in education from National Changhua University of Education, Taiwan, R.O.C. and the Ph.D degree in industrial education and technology from National Changhua University of Education in 2005. He has been a school principal in Dong-Shing Elementary School, Taiwan, R.O.C. and dealt with administrative affairs of the school. His research interests include leading, technology, and vocational education. 


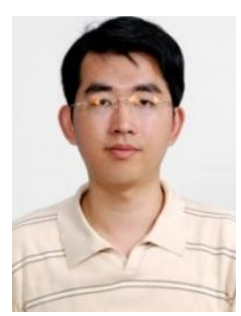

Ming-Shang Su received his M.S. degree at the Department of Industrial Education and Technology from National Changhua University of Education in 2010, and currently he is a doctoral student at the Department of Industrial Education from National Changhua University, Taiwan, R.O.C. Since August 2013, he has been a section chief of search in Changhua County Hsiushui Junior High School in Taiwan, R.O.C. Since August 2005, he has taught courses in math in the same school.

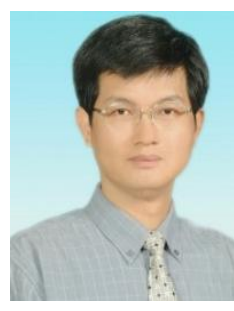

Chin-Wen Liao received both his M.S. and Ph.D. degrees in industrial education from National Taiwan Normal University, Taiwan, R.O.C. in 1994 and 2002, respectively. Since August 2011, he has been a professor in the Department of Industrial Education and Technology at National Changhua University of Education (NCUE) in Taiwan, R.O.C. He teaches courses in technology and vocational education, energy education, course and teaching, organizational learning. His research interests include technology and vocational education, teacher education, energy education of technology, and learning organization. 